\title{
Biosorption of Zinc from Aqueous Solution Using Chemically Treated Rice Husk
}

\author{
Ying Zhang, ${ }^{1,2}$ Ru Zheng, ${ }^{1}$ Jiaying Zhao, ${ }^{1}$ Yingchao Zhang, \\ Po-keung Wong, ${ }^{3}$ and Fang $\mathrm{Ma}^{2}$ \\ ${ }^{1}$ School of Resource and Environment, Northeast Agricultural University, Harbin 150030, China \\ ${ }^{2}$ State Key Laboratory of Urban Water Resource and Environment, Harbin Institute of Technology, Harbin 150090, China \\ ${ }^{3}$ School of Life Sciences, The Chinese University of Hong Kong, Shatin, NT, Hong Kong
}

Correspondence should be addressed to Fang Ma; mafang@hit.edu.cn

Received 11 March 2013; Revised 29 May 2013; Accepted 29 May 2013

Academic Editor: Abdelwahab Omri

Copyright (C) 2013 Ying Zhang et al. This is an open access article distributed under the Creative Commons Attribution License, which permits unrestricted use, distribution, and reproduction in any medium, provided the original work is properly cited.

In this study, adsorption of zinc onto the adsorbent (untreated rice husk and $\mathrm{NaOH}$-treated rice husk) was examined. During the removal process, batch technique was used, and the effects of $\mathrm{pH}$ and contact time were investigated. Langmuir isotherm was applied in order to determine the efficiency of $\mathrm{NaOH}$-treated rice husk used as an adsorbent. The zinc adsorption was fast, and equilibrium was attained within $30 \mathrm{~min}$. The maximum removal ratios of zinc for untreated rice husk and $\mathrm{NaOH}$-treated rice husk after $1.5 \mathrm{~h}$ were $52.3 \%$ and $95.2 \%$, respectively, with initial zinc concentration of $25 \mathrm{mg} / \mathrm{L}$ and optimum $\mathrm{pH}$ of 4.0 . Data obtained from batch adsorption experiments fitted well with the Langmuir isotherm model. Maximum adsorption capacity of zinc onto untreated rice husk and $\mathrm{NaOH}$-treated rice husk was $12.41 \mathrm{mg} / \mathrm{g}$, and $20.08 \mathrm{mg} / \mathrm{g}$ respectively, at adsorbent dosage of $1 \mathrm{~g} / \mathrm{L}$ at $25^{\circ} \mathrm{C}$. The nature of functional groups (i.e., amino, carboxyl, and hydroxyl) and metal ion interactions was examined by the FT-IR technique. It was concluded that the $\mathrm{NaOH}$-treated rice husk had stronger adsorption capacity for $\mathrm{Zn}^{2+}$ compared with the untreated rice husk. The $\mathrm{NaOH}$-treated rice husk is an inexpensive and environmentally friendly adsorbent for $\mathrm{Zn}^{2+}$ removal from aqueous solutions.

\section{Introduction}

The environmental pollution due to toxic heavy metals is spreading through the world along with industrial progress [1]. Heavy metals are major pollutants in marine, surface water and even treated wastewaters. The specific problem associated with heavy metals in the environment is their accumulation in the food chain and their persistence in nature [2]. Zinc is an ubiquitous metal ion in soil and aquatic environments. At background levels, it is an important nutrient, but at elevated concentrations due to anthropogenic processes, zinc becomes toxic. $\mathrm{Zn}^{2+}$ being in the list of priority pollutants proposed by Environmental Protection Agency (EPA) can give rise to serious poisoning cases. The main symptoms of zinc poisoning are dehydration, electrolyte imbalance, stomachache, nausea, dizziness, and incoordination in muscles [3]. Several different conventional methods applied to remove excessive heavy metals from aqueous solutions include chemical or electrochemical precipitation [4], ion exchange [5], adsorption on minerals, and reverse osmosis [6]. Among them, adsorption receives considerable interest in heavy metal removal. Active carbon adsorption was considered to be common and effective, but the cost is high [7]. For this reason, many studies have been carried out in order to find out effective and low-cost adsorbents. Different adsorbents are used in zinc removal such as chitosan and wheat shell $[8,9]$. Rice husk (as an agricultural waste) has a large quantity of production and is evaluated as an appropriate adsorbent due to its low-cost and high removal efficiency.

The purpose of this work was to understand the adsorption mechanism of zinc from aqueous solution by using untreated rice husk and $\mathrm{NaOH}$-treated rice husk. The kinetics and adsorption equilibrium of zinc onto $\mathrm{NaOH}$-treated rice 
husk were obtained from batch experiments. The FT-IR spectrum of the adsorbent was analyzed.

\section{Case Studies}

2.1. Materials and Methods. The adsorbent rice husk used in this work was obtained from Harbin Kaohezhai Farm. It was washed several times with distilled water to eliminate the nutrimental materials and impurities. It was oven dried at $60^{\circ} \mathrm{C}$ until a constant weight was attained. In order to investigate the effect of functional groups on the surface of rice husk, it was treated with $\mathrm{NaOH}(0.1 \mathrm{~mol} / \mathrm{L})$ according to the reported method [10]. Rice husk (100 g) was maintained for $24 \mathrm{~h}$ in $500 \mathrm{~mL} \mathrm{NaOH}(0.1 \mathrm{~mol} / \mathrm{L})$ solution with a stirring speed of $150 \mathrm{rpm}$ and at ambient temperature. After decantation and filtration of the solution, the $\mathrm{NaOH}-$ treated rice husk was obtained, and then this adsorbent was dried once again. The surface morphology of $\mathrm{NaOH}-$ treatedrice husk was observed by using a Scanning Electron Microscope (Model S-3400N, HITACHI). FT-IR spectrum of $\mathrm{NaOH}$-treated rice husk and $\mathrm{NaOH}$-treated rice husk loaded with $\mathrm{Zn}^{2+}$ was examined by Fourier Transform Infrared Spectrophotometer (NicoletMagne 750).

2.2. Chemicals. The $\mathrm{Zn}^{2+}$ stock solution used in this study was prepared by dissolving an accurate quantity of $\mathrm{ZnCl}_{2}$ with deionized water. All chemicals used in this study were of analytical grade, and solutions were prepared using deionized and distilled water. Standard solution of $\mathrm{Zn}^{2+}(1000 \mathrm{mg} / \mathrm{L})$ for flame atomic adsorption spectrometry was obtained from Beijing NCS Analytical Instruments Co. Ltd. In order to adjust the $\mathrm{pH}, 0.1 \mathrm{~mol} / \mathrm{L} \mathrm{HCl}$ and $\mathrm{NaOH}$ solutions were used.

2.3. Effect of Contact Time on $\mathrm{Zn}^{2+}$ Adsorption. Kinetic experiments were performed in continuously stirred flasks con-

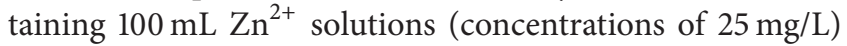
and $0.1 \mathrm{~g}$ of untreated rice husk or $\mathrm{NaOH}$-treated rice husk from 0 to $150 \mathrm{~min}$ at $25^{\circ} \mathrm{C}$ and $150 \mathrm{rpm}$. Subsequently, the mixture was filtered using an acid-cleaned $0.45 \mu \mathrm{m}$ Millipore filter, and the concentration of $\mathrm{Zn}^{2+}$ in the filtrate was analyzed by flame atomic absorption spectrometry (Model AA6800, Shimadzu, Japan). The experiment was repeated three times for each condition, and the average of the three trials was determined. The relative standard deviation (RSD) for determination of $\mathrm{Zn}^{2+}$ using this method was approximately $5 \%$.

The kinetics of $\mathrm{Zn}^{2+}$ adsorption was evaluated by applying two common models: (1) the pseudo-first-order kinetic model [11] and (2) the pseudo-second-order kinetic model [12].

The pseudo-first-order kinetic model assumes that the uptake rate of $\mathrm{Zn}^{2+}$ with time is directly proportional to the amount of available active site on the adsorbent surface. The general equation is expressed as

$$
\frac{d q_{t}}{d t}=K_{1}\left(q_{e}-q_{t}\right)
$$

where $q_{e}$ and $q_{t}$ are the uptake amount $(\mathrm{mg} / \mathrm{g})$ at equilibrium and time $t$, respectively, and $K_{1}$ is the pseudo-first-order adsorption rate constant $\left(\mathrm{min}^{-1}\right)$. Integrating equation (1) for the boundary condition $t=0$ to $t=t$ and $q_{t}=0$ to $q_{t}=q_{t}$, the linear form of (1) becomes

$$
\log \left(q_{e}-q_{t}\right)=\log q_{e}-\frac{K_{1} t}{2.303}
$$

The values of adsorption rate constant were determined from the plot of $\log \left(q_{e}-q_{t}\right)$ against $t$ (not shown) and (2). The pseudo-second-order kinetic model assumes that chemical adsorption can be the rate limiting stage involving valence forces through sharing or exchange of electrons between adsorbent and adsorbate. The pseudo-second-order kinetic equation and the linear form are

$$
\begin{aligned}
\frac{d q_{t}}{d t} & =K_{2}\left(q_{e}-q_{t}\right)^{2} \\
\frac{t}{q_{t}} & =\frac{1}{K_{2} q_{e}^{2}}+\frac{t}{q_{e}},
\end{aligned}
$$

where $K_{2}$ is the pseudo second-order adsorption rate constant $(\mathrm{g} / \mathrm{mg} \cdot \mathrm{min})$. The initial uptake rate can be obtained as $q_{e} / t$ approaches zero:

$$
h_{0}=K_{2} q_{e}^{2}
$$

where $h_{0}$ is the initial adsorption rate $(\mathrm{mg} / \mathrm{g} \cdot \mathrm{min})$. The rate constant and correlation coefficient can be calculated based on the plot (not shown) of $t / q_{t}$ versus $t$ for $\mathrm{Zn}^{2+}$ adsorption.

2.4. Effect of $\mathrm{pH}$ on $\mathrm{Zn}^{2+}$ Adsorption. A series of experiments, with $\mathrm{Zn}^{2+}$ solutions, were conducted under different $\mathrm{pH}$ values to investigate the effect of $\mathrm{pH}$ on the adsorption. The $\mathrm{pH}$ was primarily adjusted to a designated value, ranging from 1.5 to 6.0 with $0.1 \mathrm{~mol} / \mathrm{L}$ of $\mathrm{HCl}$ or $\mathrm{NaOH}$. The $100 \mathrm{~mL}$ of $25 \mathrm{mg} / \mathrm{L} \mathrm{Zn}^{2+}$ solution was then poured into a $200 \mathrm{~mL}$ flask with a stopper. The sample of untreated rice husk or $\mathrm{NaOH}$ treated rice husk of $0.1 \mathrm{~g}$ was then added to the solution, and the mixture was shaken in a temperature-controlled shaker for $4 \mathrm{~h}$ at $25^{\circ} \mathrm{C}$ and $150 \mathrm{rpm}$. The mixture was filtered, and the concentration of $\mathrm{Zn}^{2+}$ in the filtrate was determined by flame atomic absorption spectrometry.

2.5. Adsorption Equilibrium. For equilibrium studies, the concentrations of $\mathrm{Zn}^{2+}$ solutions varied from $10 \mathrm{mg} / \mathrm{L}$ to $100 \mathrm{mg} / \mathrm{L}$, and, adsorbent ( $\mathrm{NaOH}$-treated rice husk) dosage was $1 \mathrm{~g} / \mathrm{L}$. The $\mathrm{pH}$ was adjusted to 3.5 (the optimum $\mathrm{pH}$ value) by using $0.1 \mathrm{~mol} / \mathrm{L}$ of $\mathrm{HCl}$ or $\mathrm{NaOH}$ applied hourly, throughout the experiment. The mixtures were shaken for $4 \mathrm{~h}$ at $25^{\circ} \mathrm{C}$ and $150 \mathrm{rpm}$. And then they were filtered, and the concentration of $\mathrm{Zn}^{2+}$ in the filtrate was determined by flame atomic absorption spectrometry. 
Adsorption isotherms described the adsorption process and the interaction between adsorbates and adsorbents. It is important to establish the most acceptable correlations for the batch equilibrium data for analysis and design of adsorption systems. The Langmuir and Freundlich models are the most frequently used to describe the equilibrium data of adsorption. The expressions of Langmuir equation and the linear form are

$$
\begin{aligned}
q_{e} & =\frac{q_{m} k_{a} C_{e}}{\left(1+k_{a} C_{e}\right)}, \\
\frac{C_{e}}{q_{e}} & =\frac{1}{q_{m} k_{a}}+\frac{C_{e}}{q_{m}},
\end{aligned}
$$

where $C_{e}$ is the equilibrium concentration of $\mathrm{Cu}(\mathrm{II})$ in solutions $(\mathrm{mg} / \mathrm{L}), q_{m}$ is the maximum uptake amount per $\mathrm{g}$ of adsorbent $(\mathrm{mg} / \mathrm{g})$, and $k_{a}$ is the Langmuir constant related to binding energy of the sorption system $(\mathrm{L} / \mathrm{mg})$. The Langmuir parameters, $q_{m}$ and $k_{a}$, were calculated from the linear plots of $C_{e} / q_{e}$ against $C_{e}$ (not shown).

The Freundlich isotherm can be described as follows:

$$
q_{e}=K_{F} C_{e}^{1 / n}
$$

The linear form of the Freundlich isotherm is given by

$$
\log q_{e}=\log K_{F}+\left(\frac{1}{n}\right) \log C_{e}
$$

where $K_{F}$ is the Freundlich constant indicative of the relative adsorption capacity of the adsorbent and the constant $1 / n$ indicates the adsorption intensity.

The percentage removal of $\mathrm{Zn}^{2+}$ and equilibrium adsorption amount of $\mathrm{Zn}^{2+}, q_{e}(\mathrm{mg} / \mathrm{g})$, were calculated by using the following relationships:

$$
\text { percentage removal of metal ions }=\frac{100\left(C_{0}-C_{e}\right)}{C_{0}},
$$

adsorption amount of $\mathrm{Zn}^{2+}$ per gram of adsorbent (mg/g),

$$
q_{e}=\frac{\left(C_{0}-C_{e}\right) V}{w}
$$

where $C_{0}$ is the initial concentration of $\mathrm{Zn}^{2+}(\mathrm{mg} / \mathrm{L}), C_{e}$ is the equilibrium concentration of $\mathrm{Zn}^{2+}(\mathrm{mg} / \mathrm{L}), V$ is the volume of the solution (L), and $w$ is the mass of the adsorbent (g).

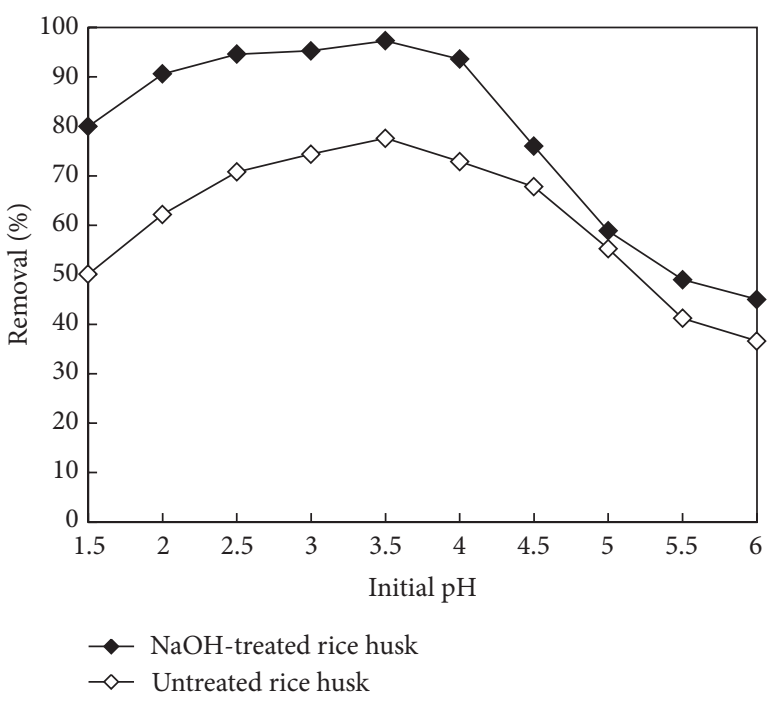

Figure 1: Effect of $\mathrm{pH}$ on the removal of $\mathrm{Zn}^{2+}$ onto untreated rice husk and $\mathrm{NaOH}$-treated rice husk $\left(\mathrm{Zn}^{2+}\right.$ concentration: $25 \mathrm{mg} / \mathrm{L}$; adsorbent dosage of $0.1 \mathrm{~g} / \mathrm{L}$, at $25^{\circ} \mathrm{C}$ ).

\section{Results and Discussion}

3.1. Effect of $\mathrm{pH}$ on $\mathrm{Zn}^{2+}$ Adsorption. Many studies have shown that $\mathrm{pH}$ is an important factor affecting absorption of heavy metals $[13,14]$. The change in initial $\mathrm{pH}$ affects the adsorptive process through dissociation of functional groups on the active sites on the surface of the adsorbent. Figure 1 shows the effect of $\mathrm{pH}$ on the removal of $\mathrm{Zn}^{2+}$ onto adsorbents from aqueous solution. It was observed that with the increase of initial $\mathrm{pH}$, the removal efficiency of $\mathrm{Zn}^{2+}$ increased firstly but decreased after attaining the $\mathrm{pH}$ of 4.0. The maximum removal was $97.3 \%$ and $77.6 \%$ at $\mathrm{pH} 3.5$ by $\mathrm{NaOH}$-treated rice husk and untreated rice husk, respectively. The change of $\mathrm{Zn}^{2+}$ removal was not obvious between $\mathrm{pH} 2.5$ and $\mathrm{pH}$ 4. Absorption increased with increasing solution $\mathrm{pH}$ since more metal binding sites could be exposed with negative charges, with subsequent attraction of metal ions with positive charges and absorption occurring onto the cell surface [15]. This phenomenon is also attributed to the fact that substantial hydrogen ions compete for vacant adsorption sites of adsorbents at lower $\mathrm{pH}$ values. A decrease in removal of $\mathrm{Zn}^{2+}$ by adsorbent was noticed at $\mathrm{pH}$ values above 4.0. With the increase of initial $\mathrm{pH}$ above $\mathrm{pH} 4$, there were more amounts of negative ions and the $\mathrm{Zn}^{2+}$ was surrounded by anions. It is difficult to combine with the adsorption sites on adsorbents surface of negative charge. Experiments were carried out up to $\mathrm{pH}$ value of 6.0 because metal precipitation occurred at higher $\mathrm{pH}$ values and interfered with the accumulation or biomass deterioration [16].

3.2. Effect of Contact Time. Figure 2 shows the effect of contact time on the extent of adsorption of $\mathrm{Zn}^{2+}$ by adsorbent. The percentage removal of $\mathrm{Zn}^{2+}$ for untreated rice husk and $\mathrm{NaOH}$-treated rice husk after 150 min was $52.3 \%$ and $95.2 \%$, 


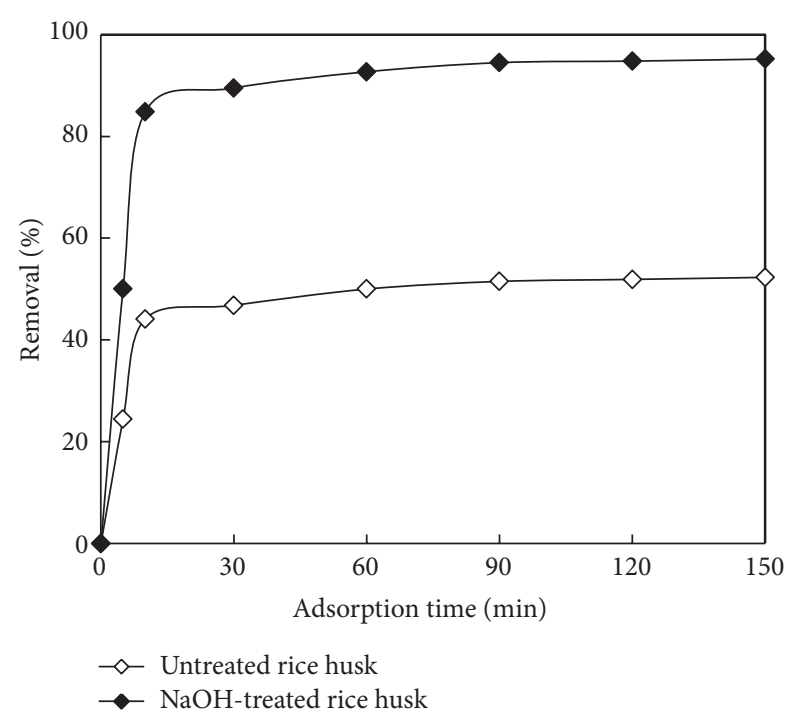

FIgURE 2: Kinetics of $\mathrm{Zn}^{2+}$ adsorption by untreated rice husk and $\mathrm{NaOH}$-treated rice husk ( $\mathrm{Zn}^{2+}$ concentration: $25 \mathrm{mg} / \mathrm{L}$; adsorbent dosage of $1 \mathrm{~g} / \mathrm{L}$, at $25^{\circ} \mathrm{C}, \mathrm{pH} 3.5$ ).

respectively, under the same experimental conditions. The percentage removal of $\mathrm{Zn}^{2+}$ was rather fast in the previous 10 minutes, but then the removal significantly decreased and eventually reached a plateau after $30 \mathrm{~min}$. This phenomenon may be related to the vacant adsorption sites on adsorbent surface. During the initial stage of sorption, a large number of vacant surface sites are available for adsorption. After lapse of time, the remaining vacant surface sites can be occupied difficultly due to repulsive forces between the solute molecules on adsorbent surface and the bulk phase [17]. And there were fewer vacant surface active sites that could be occupied by metal ions after lapse of time. The data obtained from this experiment was further used successfully to evaluate the kinetics of the adsorption process.

Adsorption kinetics, which is one of the important characteristics defining the efficiency of sorption, described the solute uptake rate. The rate constants and correlation coefficients of kinetics for the $\mathrm{Zn}^{2+}$ adsorption are presented in Table 1. Results show that the adsorption process of untreated rice husk and $\mathrm{NaOH}$-treated rice husk both fitted better with the pseudo-second-order model with $R^{2}$ of 0.9974 and 0.9912 , respectively. The adsorption amount and rate of $\mathrm{NaOH}$-treated rice husk were significant compared with untreated rice husk significantly.

3.3. Adsorption Isotherm for NaOH-Treated Rice Husk. The equilibrium adsorption isotherm is one of the most important data to understand the adsorption mechanisms. As indicated in Figure 3, the isothermal curve of $\mathrm{Zn}^{2+}$ for $\mathrm{NaOH}-$ treated rice husk showed a typical Langmuir-type pattern. The relationship between the reciprocal of the amount of $\mathrm{Zn}^{2+}$ adsorbed on $\mathrm{NaOH}$-treated rice husk and the reciprocal of the equilibrium concentration of $\mathrm{Zn}^{2+}$ in the solution was linear. Adsorption capacity $\left(q_{e}\right)$ was determined based on

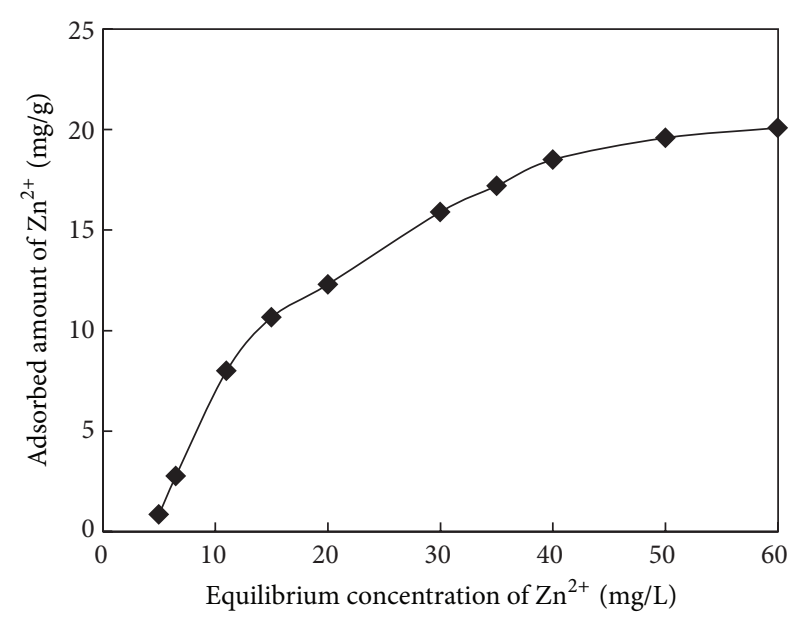

FIgURE 3: Adsorption isotherms of $\mathrm{Zn}^{2+}$ by $\mathrm{NaOH}$-treated rice husk (adsorbent dosage of $1 \mathrm{~g} / \mathrm{L}$, at $25^{\circ} \mathrm{C}, \mathrm{pH} 3.5$ ).

the adsorption isotherms of untreated rice husk and $\mathrm{NaOH}$ treated rice husk.

The parameters of adsorption isotherms for untreated rice husk and $\mathrm{NaOH}$-treated rice husk are shown in Table 2. Results show that the adsorption process fitted well with the Langmuir isotherm model with correlation coefficient $\left(R^{2}\right)$ of 0.9976 and 0.9985 for untreated rice husk and $\mathrm{NaOH}$ treated rice husk, respectively. Within the Langmuir model, the saturation adsorption capacity $q_{m}$ is supposed to coincide with saturation of a fixed number of identical surface sites and as such, it should logically be independent of temperature [21]. Maximum adsorption capacity of $\mathrm{Zn}^{2+}$ onto $\mathrm{NaOH}-$ treated rice husk had been improved obviously compared with untreated rice husk. The results obtained from this study were found to be higher than those of many corresponding biosorbents reported in the literature (Table 3) [18-20, 22].

3.4. Characterization of $\mathrm{NaOH}$-Treated Rice Husk. Scanning electron micrographs of untreated rice husk and $\mathrm{NaOH}$ treated rice husk are shown in Figure 4. At low power electron microscope, some regular and isscross framework constructions can be observed on the surface of the untreated rice husk in Figure 4(a). Embossments approximated cone and epidermal villi like needle can be seen between the two lines of framework. The surface morphological structure of $\mathrm{NaOH}$-treated rice husk is shown in Figure 4(b). There were a lot of "point spots" on cell wall and regular and criss-cross skeleton structure. The lipid, protein, and soluble polysaccharide in the rice husk were dissolved as the rice husk was treated with $\mathrm{NaOH}$. The surface structure on the cell was loose, and the physical and chemical property of rice husk was improved. This morphological structure of $\mathrm{NaOH}$ treated rice husk is conductive to the uptake of metal ions. And the structure of the adsorbent meant that the $\mathrm{NaOH}$ treated rice husk cell wall plays an important role in the $\mathrm{Zn}^{2+}$ adsorption process.

The FT-IR absorbance spectrum of $\mathrm{NaOH}$-treated rice husk and $\mathrm{NaOH}$-treated rice husk loaded with $\mathrm{Zn}^{2+}$ is shown 
TABLE 1: Kinetic parameters for the adsorption of $\mathrm{Zn}^{2+}$ by untreated rice husk and $\mathrm{NaOH}$-treated rice husk.

\begin{tabular}{|c|c|c|c|c|c|c|c|}
\hline \multirow{2}{*}{ Adsorbent } & \multicolumn{3}{|c|}{ Pseudo-first-order model } & \multicolumn{4}{|c|}{ Pseudo-second-order model } \\
\hline & $K_{1}\left(\min ^{-1}\right)$ & $q_{e}(\mathrm{mg} / \mathrm{g})$ & $R^{2}$ & $K_{2}(\mathrm{~g} / \mathrm{mg} \cdot \min )$ & $q_{e}(\mathrm{mg} / \mathrm{g})$ & $h_{0}(\mathrm{mg} / \mathrm{g} \cdot \mathrm{min})$ & $R^{2}$ \\
\hline Untreated rice husk & 0.02 & 7.59 & 0.9507 & 0.0008 & 10.27 & 0.0844 & 0.9974 \\
\hline $\mathrm{NaOH}$-treated rice husk & 0.03 & 16.90 & 0.9719 & 0.0017 & 22.83 & 0.8861 & 0.9912 \\
\hline
\end{tabular}

TABLE 2: Isotherm parameters for the adsorption of $\mathrm{Zn}^{2+}$ by untreated rice husk and $\mathrm{NaOH}$-treated rice husk.

\begin{tabular}{lccccc}
\hline Adsorbent & \multicolumn{3}{c}{ Freundlich model } & \multicolumn{3}{c}{ Langmuir model } \\
& $K_{F}$ & $1 / n$ & $R^{2}$ & $k_{a}(\mathrm{~L} / \mathrm{mg})$ & $q_{m}(\mathrm{mg} / \mathrm{g})$ \\
\hline Untreated rice husk & 0.47 & 0.36 & 0.9303 & 12.84 & 12.41 \\
NaOH-treated rice husk & 2.21 & 0.80 & 0.9732 & 7.32 & 20.08 \\
\hline
\end{tabular}

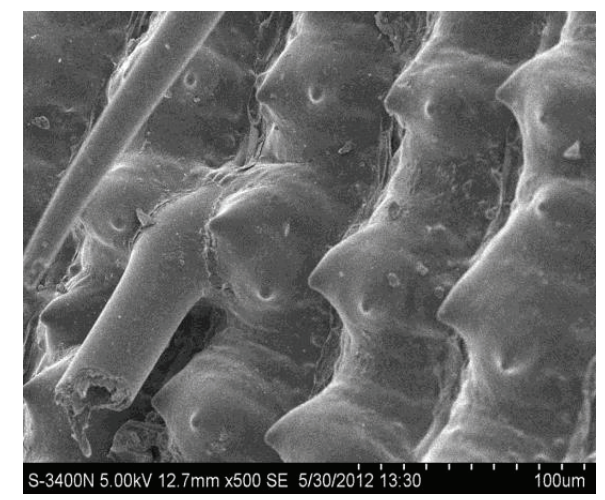

(a)

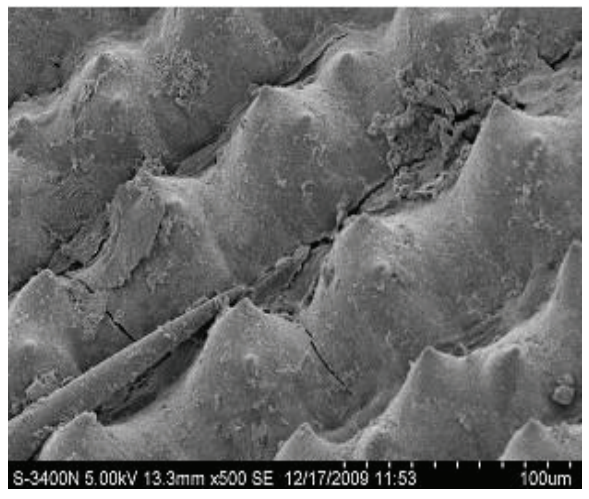

(b)

FIGURE 4: Scanning electron micrographs of (a) untreated rice husk and (b) $\mathrm{NaOH}$-treated rice husk.

in Figure 5. The peaks at $3400.27 \mathrm{~cm}^{-1}, 1406.01 \mathrm{~cm}^{-1}$, and $1033.77 \mathrm{~cm}^{-1}$ were due to amino, carboxyl, and hydroxyl groups existence on the cell wall of $\mathrm{NaOH}$-treated rice husk. It can be seen that after adsorbing $\mathrm{Zn}^{2+}$, the peaks at $3400.27 \mathrm{~cm}^{-1}, 1406.01 \mathrm{~cm}^{-1}$, and $1033.77 \mathrm{~cm}^{-1}$ reduced to $3398.34 \mathrm{~cm}^{-1}, 1386.72 \mathrm{~cm}^{-1}$ and $1041.49 \mathrm{~cm}^{-1}$, respectively, which suggested that amino, carboxyl, and hydroxyl groups could combine intensively with $\mathrm{Zn}^{2+}$. The analysis of the FT-IR spectrum showed the presence of ionisable functional groups (i.e., amino, carboxyl, and hydroxyl) able to interact with metal ions. Kapoor and Viraraghavan had shown that

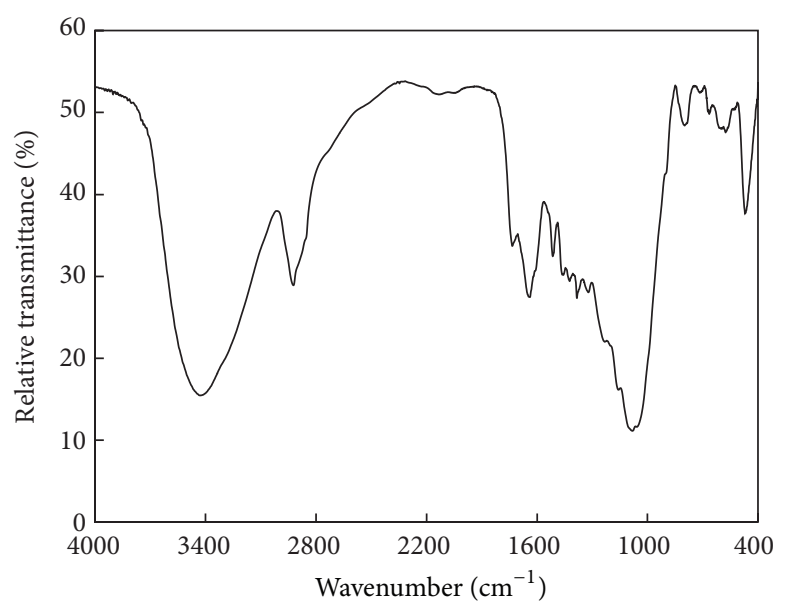

(a)

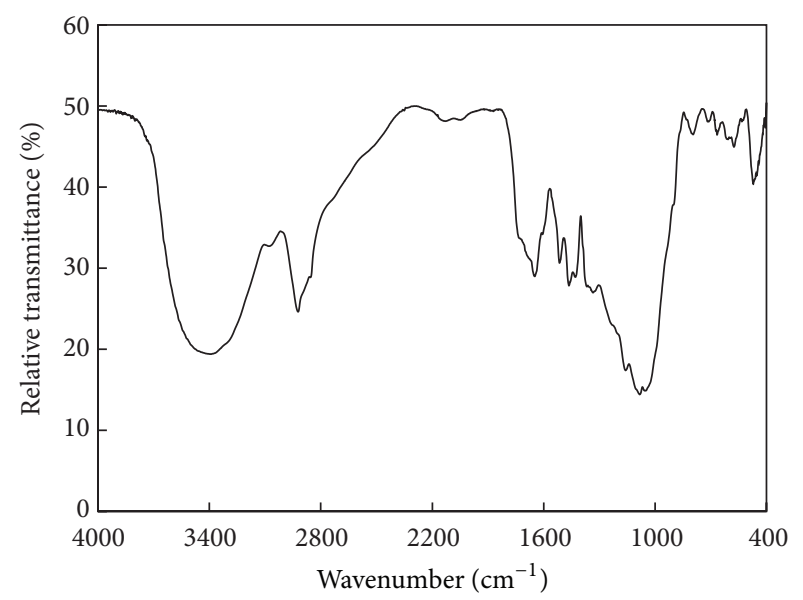

(b)

FIGURE 5: FT-IR spectrum of (a) NaOH-treated rice husk and (b) $\mathrm{NaOH}$-treated rice husk loaded with $\mathrm{Zn}^{2+}$.

esterification of carboxyl groups or methylation of amino groups of Aspergillus niger biomass severely inhibited the Lead biosorption [23]. Bai and Abraham had revealed that acetylations of amino and hydroxyl groups of Rhizopus nigricans biomass obviously reduced the chromium absorption 
TABLE 3: Adsorption of $\mathrm{Zn}^{2+}$ from the literature by various adsorbents.

\begin{tabular}{lcc}
\hline Adsorbents & Adsorption capacity (mg/g) & Reference \\
\hline Activated carbon obtained from agricultural by-products & 6.65 & Ferro-García et al. [18] \\
Oxidised jute & 8.02 & Shukla and Pai [19] \\
Neem bark & 13.29 & Bhattacharya et al. [20] \\
Black gram husk & 13.45 & Saeed et al. [9] \\
Clarified sludge & 15.53 & Bhattacharya et al. [20] \\
NaOH-treated rice husk & 20.08 & This study \\
\hline
\end{tabular}

[24]. These facts indicated the important role played by carboxyl, amino, and hydroxyl groups in the absorption of heavy metals. It suggested that ion exchange should be the principal mechanism for $\mathrm{Zn}^{2+}$ biosorption by using $\mathrm{NaOH}-$ treated rice husk.

\section{Conclusion}

The adsorption properties of $\mathrm{Zn}^{2+}$ by untreated rice husk and $\mathrm{NaOH}$-treated rice husk were examined in this experiment. The saturated adsorption amount of $\mathrm{Zn}^{2+}$ on $\mathrm{NaOH}$-treated rice husk was $20.08 \mathrm{mg} / \mathrm{g}$. The maximum removal of $\mathrm{Zn}^{2+}$ for untreated rice husk and $\mathrm{NaOH}$-treated rice husk after $150 \mathrm{~min}$ was $52.3 \%$ and $95.2 \%$ at optimum $\mathrm{pH}$ of 3.5 , respectively. The data of FT-IR spectrum confirmed the presence of ionisable functional groups (i.e., amino, carboxyl, and hydroxyl), and they were able to interact with $\mathrm{Zn}^{2+}$. This study shows that the $\mathrm{NaOH}$-treated rice husk is an inexpensive and environmentally friendly adsorbent for $\mathrm{Zn}^{2+}$ removal from wastewater.

\section{Conflict of Interests}

All authors declared that they have no conflict of interests.

\section{Acknowledgments}

This work was supported by the National Natural Science Foundation of China (no. 41101526), Open Project of State Key Laboratory of Urban Water Resource and Environment, Harbin Institute of Technology (QAK201013), Chang Jiang Scholar Candidates Program for Provincial Universities in Heilongjiang (CSCP, 2012CJHB001), and the National Scientific and Technological Supporting Project, China (2011BAD04B02).

\section{References}

[1] V. K. Gupta, M. Gupta, and S. Sharma, "Process development for the removal of lead and chromium from aqueous solutions using red mud-an aluminium industry waste," Water Research, vol. 35, no. 5, pp. 1125-1134, 2001.

[2] N. Friis and P. Myers-Keith, "Biosorption of uranium and lead by Streptomyces longwoodensis," Biotechnology and Bioengineering, vol. 28, no. 1, pp. 21-28, 1986.

[3] C. K. Jain, D. C. Singhal, and M. K. Sharma, "Adsorption of zinc on bed sediment of River Hindon: adsorption models and kinetics," Journal of Hazardous Materials, vol. 114, no. 1-3, pp. 231-239, 2004.

[4] J. O. Esalah, M. E. Weber, and J. H. Vera, "Removal of lead, cadmium and zinc from aqueous solutions by precipitation with sodium di-(n-octyl) phosphinate," Canadian Journal of Chemical Engineering, vol. 78, no. 5, pp. 948-954, 2000.

[5] V. D. A. Cardoso, A. G. D. Souza, P. P. C. Sartoratto, and L. M. Nunes, "The ionic exchange process of cobalt, nickel and copper(II) in alkaline and acid-layered titanates," Colloids and Surfaces A, vol. 248, no. 1-3, pp. 145-149, 2004.

[6] D. Buerge-Weirich, R. Hari, H. Xue, P. Behra, and L. Sigg, "Adsorption of $\mathrm{Cu}, \mathrm{Cd}$, and $\mathrm{Ni}$ on goethite in the presence of natural groundwater ligands," Environmental Science and Technology, vol. 36, no. 3, pp. 328-336, 2002.

[7] S. Babel and T. A. Kurniawan, "Low-cost adsorbents for heavy metals uptake from contaminated water: a review," Journal of Hazardous Materials, vol. 97, no. 1-3, pp. 219-243, 2003.

[8] G. McKay, H. S. Blair, and A. Findon, "Equilibrium studies for the sorption of metalions onto chitosan," Indian Journal of Chemistry A, vol. 28, pp. 356-360, 1989.

[9] A. Saeed, M. W. Akhter, and M. Iqbal, "Removal and recovery of heavy metals from aqueous solution using papaya wood as a new biosorbent," Separation and Purification Technology, vol. 45, no. 1, pp. 25-31, 2005.

[10] A. Selatnia, M. Z. Bakhti, A. Madani, L. Kertous, and Y. Mansouri, "Biosorption of $\mathrm{Cd}^{2+}$ from aqueous solution by a $\mathrm{NaOH}$-treated bacterial dead Streptomyces rimosus biomass," Hydrometallurgy, vol. 75, no. 1-4, pp. 11-24, 2004.

[11] K. G. Bhattacharyya and A. Sharma, "Azadirachta indica leaf powder as an effective biosorbent for dyes: a case study with aqueous Congo Red solutions," Journal of Environmental Management, vol. 71, no. 3, pp. 217-229, 2004.

[12] Y. S. Ho and G. McKay, "Pseudo-second order model for sorption processes," Process Biochemistry, vol. 34, no. 5, pp. 451465, 1999.

[13] C. P. Huang, C. P. Huang, and A. L. Morehart, "The removal of $\mathrm{Cu}$ (II) from dilute aqueous solutions by Saccharomyces cerevisiae," Water Research, vol. 24, no. 4, pp. 433-439, 1990.

[14] A. Sánchez, A. Ballester, M. L. Blázquez, F. González, J. Muñoz, and A. Hammaini, "Biosorption of copper and zinc by Cymodocea nodosa," FEMS Microbiology Reviews, vol. 23, no. 5, pp. 527-536, 1999.

[15] S. R. Taffarel and J. Rubio, "On the removal of $\mathrm{Mn}^{2+}$ ions by adsorption onto natural and activated Chilean zeolites," Minerals Engineering, vol. 22, no. 4, pp. 336-343, 2009.

[16] P. R. Puranik and K. M. Paknikar, "Biosorption of lead and zinc from solutions using Streptoverticillium cinnamoneum waste biomass," Journal of Biotechnology, vol. 55, no. 2, pp. 113-124, 1997. 
[17] J. Wongjunda and P. Saueprasearsit, "Biosorption of chromium (VI) using rice husk ash and modified rice husk ash," Environmental Research Journal, vol. 4, no. 3, pp. 244-250, 2010.

[18] M. A. Ferro-García, J. Rivera-Utrilla, J. Rodríguez-Gordillo, and I. Bautista-Toledo, "Adsorption of zinc, cadmium, and copper on activated carbons obtained from agricultural by-products," Carbon, vol. 26, no. 3, pp. 363-373, 1988.

[19] S. R. Shukla and R. S. Pai, "Adsorption of $\mathrm{Cu}(\mathrm{II}), \mathrm{Ni}(\mathrm{II})$ and Zn(II) on modified jute fibres," Bioresource Technology, vol. 96, no. 13, pp. 1430-1438, 2005.

[20] A. K. Bhattacharya, S. N. Mandal, and S. K. Das, "Adsorption of $\mathrm{Zn}(\mathrm{II})$ from aqueous solution by using different adsorbents," Chemical Engineering Journal, vol. 123, no. 1-2, pp. 43-51, 2006.

[21] J. Febrianto, A. N. Kosasih, J. Sunarso, Y. Ju, N. Indraswati, and S. Ismadji, "Equilibrium and kinetic studies in adsorption of heavy metals using biosorbent: a summary of recent studies," Journal of Hazardous Materials, vol. 162, no. 2-3, pp. 616-645, 2009.

[22] A. Saeed, M. Iqbal, and M. W. Akhtar, "Removal and recovery of lead(II) from single and multimetal (Cd, $\mathrm{Cu}, \mathrm{Ni}, \mathrm{Zn}$ ) solutions by crop milling waste (black gram husk)," Journal of Hazardous Materials, vol. 117, no. 1, pp. 65-73, 2005.

[23] A. Kapoor and T. Viraraghavan, "Heavy metal biosorption sites in Aspergillus niger," Bioresource Technology, vol. 61, no. 3, pp. 221-227, 1997.

[24] R. S. Bai and T. E. Abraham, "Studies on enhancement of $\mathrm{Cr}(\mathrm{VI})$ biosorption by chemically modified biomass of Rhizopus nigricans," Water Research, vol. 36, no. 5, pp. 1224-1236, 2002. 

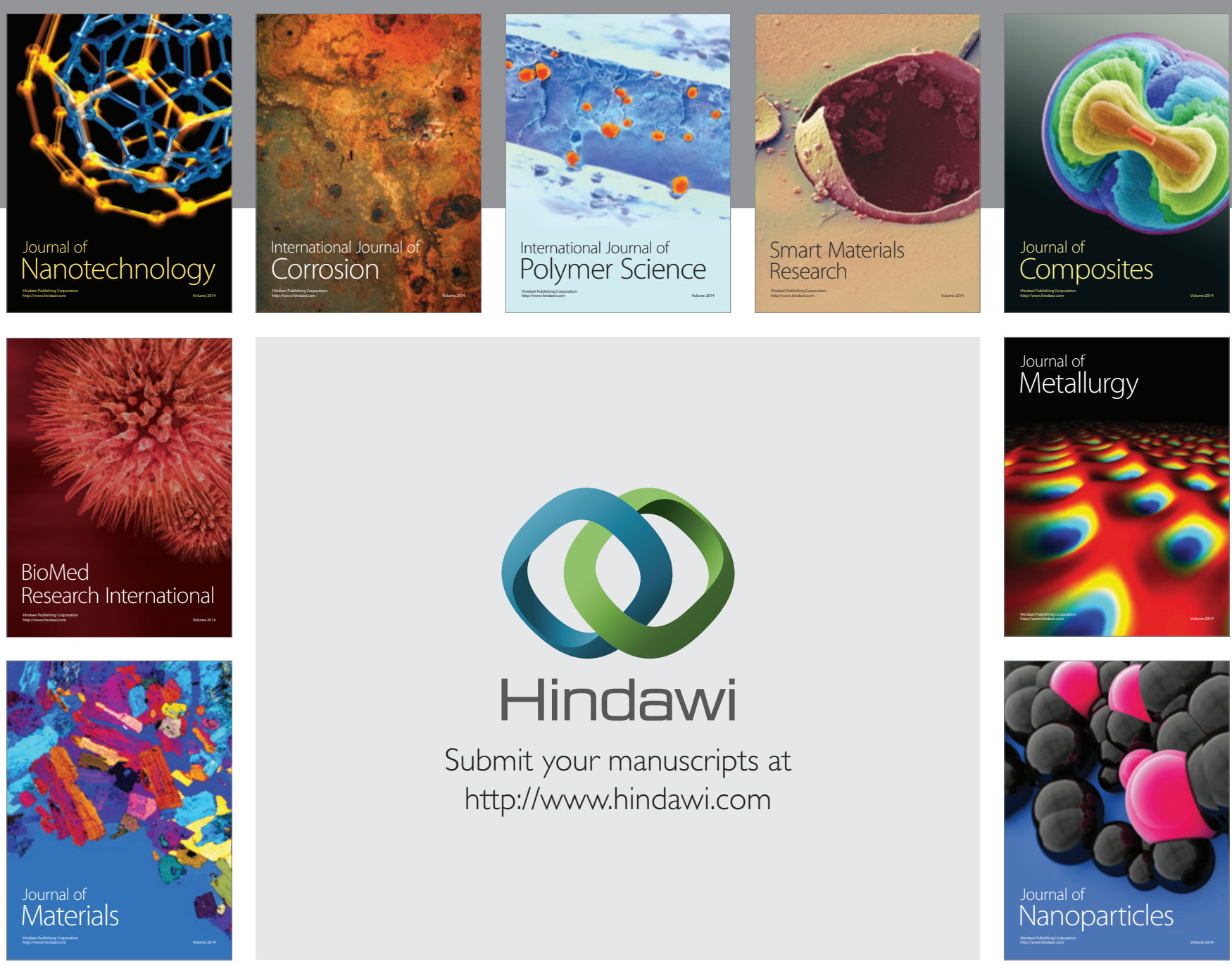

Submit your manuscripts at http://www.hindawi.com
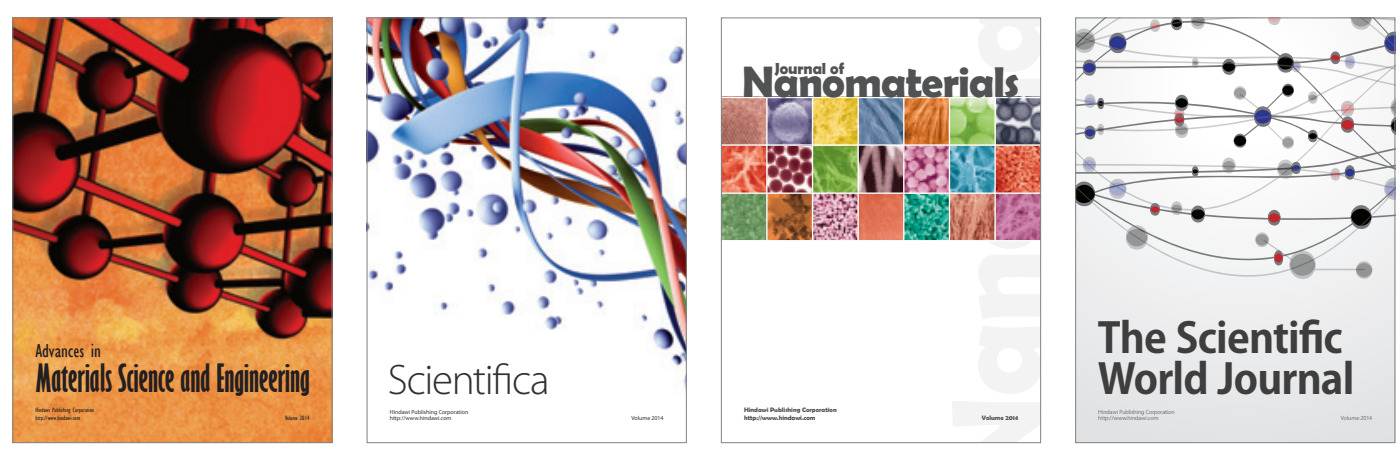

\section{The Scientific World Journal}
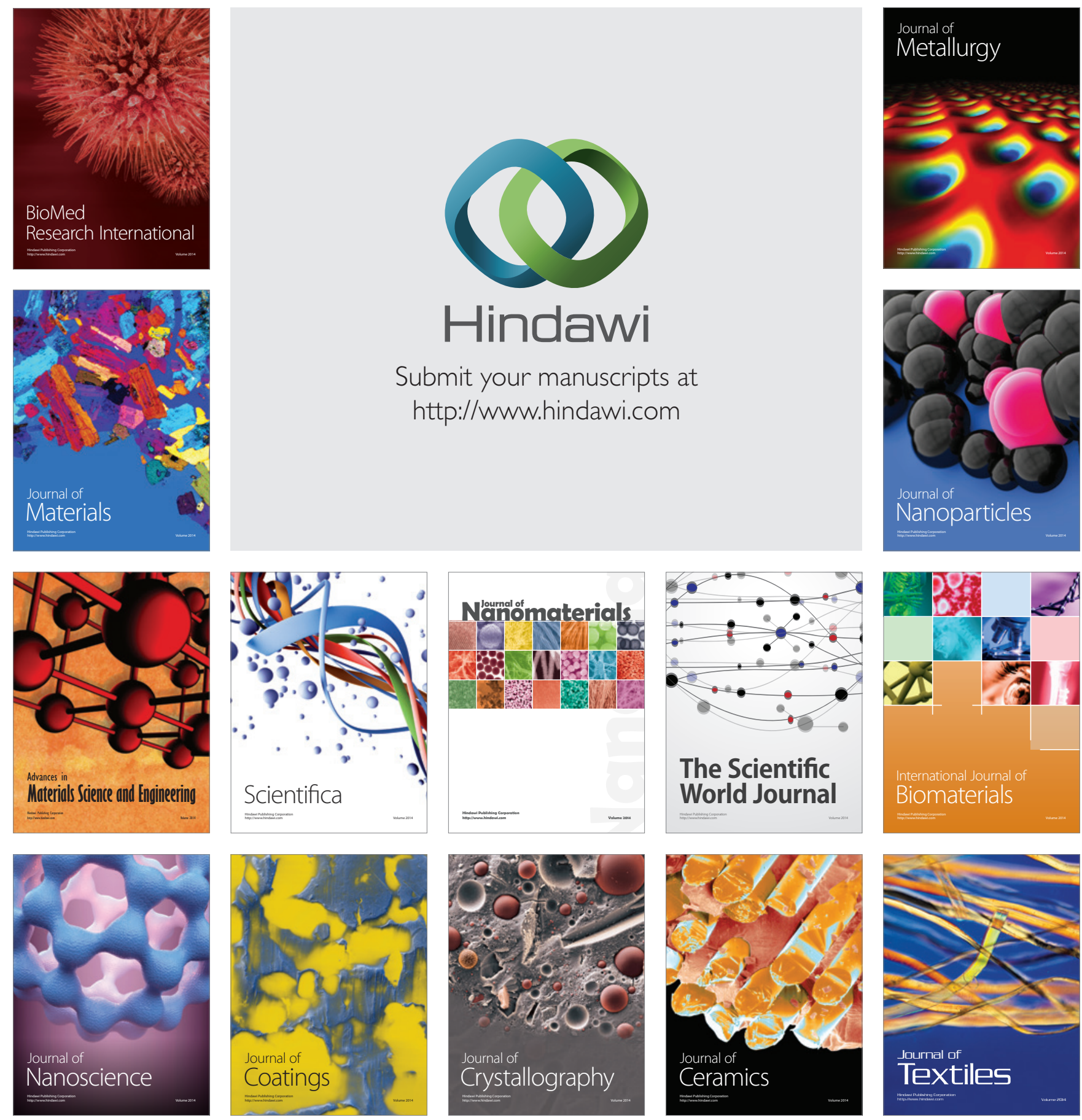